\title{
Sterilization and Callus Formation of Rubber Meristem (Hevea brasiliensis Muell. Arg.)
}

\author{
Dwi Sucianingtyas Sukamto
}

Biology Education Study Program, FP-MIPA IKIP PGRI Jember

J1. Jawa No.10 Jember 68121, East Java, Indonesia

Tel: (0331)335977Ｅ-mail: dwisucianingtyas@gmail.com

Lila Maharani

Biology Education Study Program, FP-MIPA IKIP PGRI Jember

Jl. Jawa No.10 Jember 68121, East Java, Indonesia

Tel: (0331)335977Ｅ-mail: lilarani82@gmail.com

Siti Amalia

Biology Education Study Program, FP-MIPA IKIP PGRI Jember

J1. Jawa No.10 Jember 68121, East Java, Indonesia

Tel: (0331)335977Ｅ-mail: s.amalia032@gmail.com

Sholeh Avivi

Agronomy Study Program of Agriculture Faculty in Jember University

Jl. Kalimantan No. 37 Kampus Tegal Boto Jember 68121, East Java, Indonesia

$$
\text { Tel : (0331) } 330224 \quad \text { E-mail: savivi.faperta@unej.ac.id }
$$

Didik Pudji Restanto

Agronomy Study Program of Agriculture Faculty in Jember University

Jl. Kalimantan No. 37 Kampus Tegal Boto Jember 68121, East Java, Indonesia

Tel : (0331) $330224 \quad$ E-mail: didik_lemlit@unej.ac.id

Received: September 6, 2018 Accepted: October 8, 2018

doi:10.5296/jas.v6i4.13796 URL: https://doi.org/10.5296/jas.v6i4.13796 


\section{Abstract}

Rubber plant (Hevea brasiliensis Muell Arg) is one of the important plantation commodities in Indonesia because of its role as a source of income. It stimulates the economic growth around the rubber plantation area. The propagation of rubber is still using conventional methods like grafting. The technique of tissue culture through callus induction is one of the alternatives of mass propagation of rubber seedling with quick and efficient time. The sterilization method is very important to determine the success of tissue culture techniques. Therefore, the aim of this research is to know the best method of sterilization and callus formation in rubber explants. The basic media used were WPM and MS, with BAP of $2 \mathrm{ppm}$ and NAA $0.1 \mathrm{ppm}$. The best result of sterilization is by soaking $5 \%$ fungicide solution for 5 minutes, $5 \%$ Clorox solution for 15 minutes, betadin $10 \%$ solution for 5 minutes, and finally it rinsed with sterile water three times. The best medium uses WPM medium for callus induction, with $0.5 \mathrm{~cm}$ callus length and embryonic callus. In contrast, the MS medium has $0.4 \mathrm{~cm}$ callus length and non embryonic callus.

Keywords: Sterilization, Callus induction, Rubber ((Hevea brasiliensis Muell Arg)

\section{Introduction}

Rubber is the output of plantations in Indonesia which is the second largest export commodity after palm oil. Based on the data from the Directorate General of Plantations, rubber exports reached 2,701,995 tons in 2013. In 2014, Indonesia's rubber production reached 3,400,000 tons, while Thailand reached 4,070,000 tons. As the second largest rubber producer in the world, Indonesia's supply of rubber is important for the global market. However, compared to other rubber-producing countries, Indonesia has a low productivity level per hectare. Indonesia produces only $1,080 \mathrm{~kg} / \mathrm{ha}$ while Thailand produces 1,800 kilograms $(\mathrm{kg})$ of rubber per hectare per year, Vietnam $(1,720 \mathrm{~kg} / \mathrm{ha})$ Malaysia $(1,510 \mathrm{~kg} / \mathrm{ha})$ has higher rubber productivity.

Propagation of rubber seedlings until now is still done by grafting, so it needs the availability of upper stems and rootstock. The upper stem is clone rubber plant because it is propagated from the vegetative part using the bud eye, while the rootstock is the seed plant. Rootstock is the origin of seed plants (seedlings) so its availability depends on the season of seed are generally only lasted once in a year. The weakness of this technique among others is that it takes a long time, about 18 months from germination to transplantation of the seedlings is ready to be moved to the field. It is often a constraint to conventionally produce seeds on a mass scale. Another disadvantage of the use of seed from seed as rootstock is the diversity of the rootstock and the potential of production and other superior characters is reduced due to different levels of juvenility (Seneviratne, 1996).

One of the alternatives to meet the increasing demand for rubber seeds and not depending on the season is by using plant tissue culture techniques (Montoro, et al. 2010). The in vitro culture of rubber can be done by microcutting and somatic embryogenesis (Nayanakantha \& Seneviratne, 2007; Montoro et al., 2010).

The factors that determine the success of tissue culture is a growth regulator substance and explantss preparation, explantss sterilization and browning (Seneviratne, 1996). Tissue culture 
media designed for woody plants such as fruits are the WPM result of the composition from Llyoyd and McCown (1981). This medium is consistent as a medium for woody plants developed by other experts, but the sulfate used is higher than sulfate in other woody media. Giving the concentrate combination of BAP and NAA in WPM media has an influence towards the percentage of explants forming shoots (Moradpour, et al. 2016).

Several studies still show the success of embryonic callus culture. Embryonic callus is a callus that has the potential to form somatic embryos. Therefore, optimization of sterilization and callus formation on a PGR combination and the appropriate media needs to be done, so it can be used to produce high quality rubber plant seeds and produce a standard protocol that can be used in the induction of somatic embryogenesis of the plants.

\section{Materials and Methods}

\subsection{Place and Time}

This research was conducted in Culture Tissue Laboratory of IKIP PGRI Jember from May to July 2017. The material used is the apical shoots of rubber plant taken from the entre garden of rubber plants in PT. Perkebunan Nusantara XII Kebun Renteng, Ajung, Jember.

\subsection{Research Design}

This research uses Factorial Complete Randomized Design (F-CRD) with 2 treatment factors, i.e. basic media type and the combination of PGR concentration.

Factor 1: media type

a. MS

b. WPM

Factor 2: PGR concentration

a. $\mathrm{BAP}=2 \mathrm{mg} / \mathrm{L}$

b. $\mathrm{NAA}=0.1 \mathrm{mg} / \mathrm{L}$

To determine the repetition of an experiment using the complete randomized design (CRD) formula are as follows:

$(\mathrm{t}-1)(\mathrm{r}-1) \geq 15$

$(8-1)(\mathrm{r}-) \geq 15$

$r \geq 23 / 8$

$\mathrm{r}=3$

Based on the above-mentioned formula, the repetition is done as many as five times of repetitions.

The research layout for each experiment is presented in the form of table 1 . 
Table 1. Research layout

\begin{tabular}{l|l|l|l|l}
\hline No & Sample & U1 & U2 & U3 \\
\hline 1. & P1 & P2 U1 & P4 U3 & P1 U1 \\
\hline 2. & P2 & P7 U3 & P6 U3 & P5 U3 \\
\hline 3. & P3 & P5 U2 & P7 U2 & P3 U1 \\
\hline 4. & P4 & P8 U2 & P3 U3 & P3 U2 \\
\hline 5. & P5 & P8 U1 & P6 U2 & P5 U1 \\
\hline 6. & P6 & P4 U1 & P8 U3 & P7 U1 \\
\hline 7. & P7 & P4 U2 & P1 U2 & P2 U2 \\
\hline 8. & P8 & P2 U3 & P1 U3 & P6 U1 \\
\hline
\end{tabular}

Information:

$\mathrm{P}=$ treatment

$\mathrm{U}=$ repetition

$\mathrm{P} 1=\mathrm{WPM}$ treatment

$\mathrm{P} 2=\mathrm{WPM}+\mathrm{BAP}$ treatment $(2 \mathrm{mg} / \mathrm{L})$
$\mathrm{P} 3=\mathrm{WPM}+\mathrm{NAA}$ treatment $(0.1 \mathrm{mg} / \mathrm{L})$

$\mathrm{P} 4=\mathrm{WPM}+\mathrm{BAP}$ treatment $(2 \mathrm{mg} / \mathrm{L})+\mathrm{NAA}(0.1 \mathrm{mg} / \mathrm{L})$

$\mathrm{P} 5=\mathrm{MS}$ treatment

$\mathrm{P} 6=$ treatment of MS + BAP $(2 \mathrm{mg} / \mathrm{L})$

$\mathrm{P} 7=$ treatment of $\mathrm{MS}+\mathrm{NAA}(0.1 \mathrm{mg} / \mathrm{L})$

\subsection{Materias}

The tools used in this study is a Petri dish, stir bar, measuring cups, Erlenmeyer, culture bottles, scalpel, tweezers, scissors, LAF (Laminar Air Flow), analytic scale, oven, autoclave, Bunsen lamp, alcohol sprayer, Culture shelf, aluminum foil, tissue, plastic wrap, rubber band, filter paper, hand sprayer, $\mathrm{pH}$ meter, measuring pipette, matches, cotton, tissue and stationery.

Materials used include rubber, base medium, i.e. WPM and MS, BAP 2 mg/L, NAA $0.1 \mathrm{mg} / \mathrm{L}$, $70 \%$ of alcohol and $95 \%$ of Aquades, sugar, agar, Clorox and rubbing alcohol.

\subsection{Methods}

\subsubsection{Research Preparation}

The first step is to prepare all the needs in the research phase including administration and materials and places needed. Determine where the research will be conducted in vitro for the manufacture of media and planting meristem tissue buds of rubber plants in order to obtain sterile results.

\subsubsection{Sterilization of Tools and Materials}

All the tools to be used are washed and dried. Sterilization was performed on autoclave at $121^{\circ} \mathrm{C}$ for 30 minutes. The reaction tube, measuring cup, and Erlenmeyer were covered with cotton. Petri dish is wrapped with paper. All seeding media are sterilized. Tweezers and ose needles are sterilized by means of smoothing on a bunsen flame.

\subsubsection{Production of Medium With BAP and NAA}

The media used are Murasigh and Skoog (MS) and Woody Plant Medium Media (WPM) by adding PGR in the form of BAP and NAA. The production of 1 liter of medium requires $30 \mathrm{~g} / \mathrm{l}$ 
of sugar, then added aquades up to 1 liter volume. The media is adjusted to its acidity ( $\mathrm{pH}$ ) level of 6.0. The addition and reduction of $\mathrm{pH}$ is done by adding $\mathrm{KOH} 1 \mathrm{~N}$ and $\mathrm{HCl} 1 \mathrm{~N}$ to reach the desired $\mathrm{pH}$. The $\mathrm{pH}$-adjusted medium was added to gelatin as much as $7 \mathrm{~g} / \mathrm{L}$ and then cooked until dissolved. The media is poured into sterile culture bottles that have been prepared each 20 $\mathrm{ml}$ for each bottle. Bottle immediately sealed using plastic and tied with a rubber band and then sterilized by autoclave at $121^{\circ} \mathrm{C}$ and a pressure of 17.5 psi for 30 minutes. Furthermore, the media bottles were stored in media storage space that has been equipped with air conditioning.

\subsubsection{Planting Meristem}

Explants planting are done in Laminar Air Flow aseptically. Before explantss planted in medium then needed sterilization of tools and explantss sterilization. Sterilization of the tools is done by means of all the tools used for planting such as scalpel and tweezers dipped alcohol $70 \%$ then burned over bunsen. Sterilization explantss are done in the same way that the stem cuts under the first segment meristem apical dipped in $70 \%$ alcohol then passed on fire bunsen. Further explantss inserted into the bottle culture that has contained the media.

\subsection{Observation}

The inoculated explantss were observed based on observation parameters. The parameters observed were callus size, and callus color. Observation of texture and color callus is done visually. As well as experiencing the development process to form phases of somatic embryogenesis and when observed under a microscope the cytoplasm looks very solid.

\subsection{Data Analysis Technique}

The data obtained were analyzed using one way Anova (analysis of variance). If the value of $F$ arithmetic $\geq \mathrm{F}$ table then there is a real conception between the treatment and alternative hypothesis (Ha) accepted. Conversely, if the value of $\mathrm{F}$ arithmetic $<\mathrm{F}$ table then there is no real existence between treatment and alternative hypothesis (Ha) rejected. Then if there is a real difference, further test is done to see the difference between each treatment based on the value of coefficient of diversity (KK) obtained. The further test used was DMRT at the 5\% test level.

\section{Result}

\subsection{Sterilization}

The results showed that sterilization explants shoot apical rubber plant is by soaking using 5\% fungicide for 5 minutes, and then rinsed with sterile aquadest three times. Subsequent immersion with $5 \%$ Clorox or sodium hypochlorite $(\mathrm{NaOCl})$ solution for 15 minutes was then rinsed with sterile aquadest three times, and immersed in $10 \%$ povidone iodine solution for 5 minutes then rinsed with aquadest 3 times.

\subsection{Induction of Callus}

Percentage of explants to form buds, callus length and shoot legth showed on Table 2. 


\section{Macrothink}

Journal of Agricultural Studies

ISSN 2166-0379

2018, Vol. 6, No. 4

Table 2. The average callus length and shoot length formed for 6 weeks of apical meristem culture of rubber plants

\begin{tabular}{lccc}
\hline \multicolumn{1}{c}{ Treatment of basic media and PGR } & $\begin{array}{c}\text { Percentage of explants to } \\
\text { form buds }(\%)\end{array}$ & $\begin{array}{c}\text { Callus length } \\
(\mathrm{cm})\end{array}$ & $\begin{array}{c}\text { Shoot length } \\
(\mathrm{cm})\end{array}$ \\
\hline $\mathrm{MS}_{0}$ & $100^{\mathrm{a}}$ & $0,4^{\mathrm{a}}$ & $0,1^{\mathrm{a}}$ \\
\hline $\mathrm{MS}+\mathrm{BAP}(2 \mathrm{ppm})$ & $100^{\mathrm{a}}$ & $0,1^{\mathrm{b}}$ & $0,1^{\mathrm{a}}$ \\
\hline $\mathrm{MS}+\mathrm{NAA}(0,1 \mathrm{ppm})$ & $100^{\mathrm{a}}$ & $0,1^{\mathrm{b}}$ & $0,2^{\mathrm{a}}$ \\
\hline $\mathrm{MS}+\mathrm{BAP}(2 \mathrm{ppm})+\mathrm{NAA}(0,1 \mathrm{ppm})$ & $100^{\mathrm{a}}$ & $0,1^{\mathrm{b}}$ & $0,1^{\mathrm{a}}$ \\
\hline $\mathrm{WPM}_{0}$ & $100^{\mathrm{a}}$ & $0,5^{\mathrm{a}}$ & $0,1^{\mathrm{a}}$ \\
\hline $\mathrm{WPM}+\mathrm{BAP}(2 \mathrm{ppm})$ & $100^{\mathrm{a}}$ & $0,3^{\mathrm{ab}}$ & $0,1^{\mathrm{a}}$ \\
\hline $\mathrm{WPM}+\mathrm{NAA}(0,1 \mathrm{ppm})$ & $100^{\mathrm{a}}$ & $0,2^{\mathrm{b}}$ & $0,1^{\mathrm{a}}$ \\
\hline $\mathrm{WPM}+\mathrm{BAP}(2 \mathrm{ppm})+\mathrm{NAA}(0,1 \mathrm{ppm})$ & $100^{\mathrm{a}}$ & $0,2^{\mathrm{b}}$ & $0,1^{\mathrm{a}}$ \\
\hline
\end{tabular}

*Means followed by the same letter in the same column are not significantly different based on DMRT $(\mathrm{p}=0.05)$.

Callus from meristem apical rubber plant with each treatment showed on Figure 1.

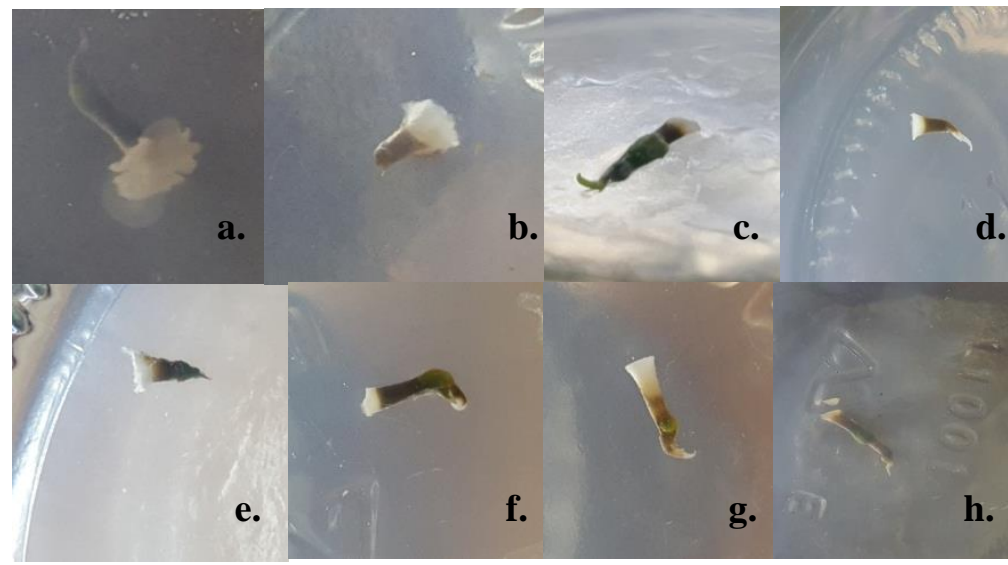

Figure 1. a. Callus from meristem apical rubber plant on WPM treatment; b. Callus from meristem apical rubber plant on MS treatment; c. The shoots of apical rubber plant apical on MS + NAA 0.1 ppm; d. Callus from meristem apical rubber plant on WPM + BAP 2 ppm + NAA $0.1 \mathrm{ppm}$; e. Callus from meristem apical rubber plant on MS + BAP 2 ppm + NAA 0.1 ppm; f. Callus from meristem apical rubber plant on WPM + NAA $0.1 \mathrm{ppm}$; g. Callus from meristem apical rubber plant on WPM + BAP $2 \mathrm{ppm}$; $\mathrm{h}$. The shoots of apical rubber plant apical on MS + BAP 2 ppm.

\section{Discussions}

Sterilization is a critical stage of successful plant tissue culture. In this study, shoots needed rubber plants, cleaned using detergent and water running (Mandubuko, 2016). The shoots are then immersed in a fungicide solution based on mankozeb, sodium hypochlorite $(\mathrm{NaOCl})$, and povidone iodine sequentially. The results showed that sterilization explants shoot apical rubber plant is by soaking using $5 \%$ fungicide for 5 minutes, and then rinsed with sterile aquadest three times. Subsequent immersion with $5 \%$ Clorox or sodium hypochlorite $(\mathrm{NaOCl})$ solution for 15 minutes was then rinsed with sterile aquadest three times, and immersed in $10 \%$ 
povidone iodine solution for 5 minutes then rinsed with aquadest 3 times.

Immersion with the solution was successful in preventing fungal and bacterial contamination in this study. Fungicides that are multisite inhibitors can inhibit some metabolic processes of the fungus (Seneviratne, 1996; Farzinebrahimi, 2013). The fungicides are also non-systemic and cannot be absorbed and trans-located in the plant tissue. The non-systemic fungicide only forms a barrier layer on the surface of the plant (usually a leaf) where the fungicide is sprayed. This fungicide only serves to prevent fungal infections by inhibiting the germination of spores or mycelia fungus attached to the surface of the plant. Sodium hypochlorite $(\mathrm{NaOCl})$ is widely used in explants sterilization (Jan et al, 2013). When sodium hypochlorite dissolves in water, two substances will form hypochlorite and hypochlorite ions. Hypochlorite acid is then degraded to form hydrochloric acid and oxygen. Oxygen is a very powerful oxidizer; therefore, sodium hypochlorite is often used to kill bacteria, viruses, and fungi. This solution is able to oxidize and hydrolyze cells and osmosis drain water out of the cell due to its hypertonic nature. Sodium hypochlorite has a pH between 11 and 12. The antimicrobial effect is able to go deeper and clean the infected area better (Mandubuko, 2016).

The result of analysis (Table 2) showed that the combination of BAP and NAA on MS and WPM media had no significant effect on the percentage of explants form callus (\%). All treatments can produce callus with a clean white color and with different sizes. The best callus is formed on the WPM treatment of $0.5 \mathrm{~cm}$ and MS $0.4 \mathrm{~cm}$ without the addition of PGR. While the shoot lengths were not significantly different in all treatments, the shoots formed $0.1 \mathrm{~cm}$ almost in each treatment.

Callus formation at all treatment occurs at the base of meristem, which is part of the wound. Callus formation in the wound tissue is spurred by growth regimens auksin and cytokinins both exogenous and endogenous in meristem. In vivo, callus is generally formed on scars due to infection of micro-organisms such as Agrobacterium tumefaciens. The process of callus formation in vitro culture is highly dependent of the type of explants, basic media and PGR used (Jayatillake, 2007; Jimenes et al., 2001). Types of basic media as well as endogenous and exogenous growth regulators have an effect on inducing certain morphogenesis patterns.

The results showed that, treatment that gives the largest callus is WPM treatment, because this medium is formulated for woody plants. The image of callus of WPM treatment and shoots on the best treatment of MS + NAA $0.1 \mathrm{ppm}$ on can be seen in Figure 1. The ion concentration in WPM is lower than that of MS (Sathyanarayana and Varghese, 2007). This medium is specially designated woody plants, and developed by other experts, but the sulfate used is higher than sulphate on WPM media. Currently WPM is widely used for propagation of ornamental plants of shrubs and trees. WPM was first formulated by Lloyd and McCown in 1981 to the formation of buds Kalmila latifolia. Since then it has been widely used for in-vitro culture of woody plants. The content of WPM is an inorganic salt of vitamins and amino acids. WPM provides all the essential macro-elements and microelements needed by plants, which play an important role in plant metabolism, carbohydrate metabolism, and enzymatic cofactors in the glycolysis cycle (Sathyanarayana and Varghese, 2007; Zhao, et al., 2015).

The important growth regulators in tissue culture are cytokines and auxins. The interactions 
and concentrations between growth regulators given in the media and those produced by cells are endogenous, determining the direction of development of a culture. The shoot length parameters give no significant difference in each treatment. NAA is an auxin that can increase protein synthesis and can be used as a source of energy in growth. Cytokinin plays a role in stimulating cell opposition, cell enlargement and division, the other cytokinin's role is to encourage the process of morphogenesis, perforation and can stimulate the growth of shoots and leaves. Auxin and cytokines, which are applied simultaneously to the culture medium, are used to induce certain morphogenesis patterns. The combination of auxin and cytokinin will spur the growth of callus, as well as spur cell division. In high concentrations of cytokinins can induce shoot proliferation and vice versa may inhibit root blockers. High BAP concentrations can cause stunted plant height (Sathyanarayana and Varghese, 2007).

\section{Conclusion}

The best result of sterilization is by soaking 5\% fungicide solution for 5 minutes, $5 \%$ Clorox solution for 15 minutes, betadin $10 \%$ solution for 5 minutes, and finally it rinsed with sterile water three times. The best medium uses WPM medium for callus induction, with $0.5 \mathrm{~cm}$ callus length and embryonic callus. In contrast, the MS medium has $0.4 \mathrm{~cm}$ callus length and non embryonic callus.

\section{Acknowledgements}

Thank you, we would like to say thank you to the parties who have helped us in this research, especially to DIKTI as the main donator for the implementation of this research with contract number $075 / \mathrm{SP} 2 \mathrm{H} / \mathrm{K} 7 / \mathrm{KM} / 2017$. We would like to also say thank you to the Department of Agriculture Technology, Faculty of Agriculture, Plant Tissue Culture laboratory for the facilities provided.

\section{References}

Farzinebrahimi, R., Taha, K. R. R. M., \& Yaacob, J. S. (2013). Effective sterilization protocol for micropropagation of Musa coccinea (Musa SPP). International Conference on Agriculture and Biotechnology, 60, 118-121.

Jan, A., Bhat, K. M., Bhat, S. J. A., Mir, M. A., Bhat, M. A., Imtiyaz, A. W., \& Rather, J. A. (2013). Surface sterilization method for reducing microbial contamination of field grown strawberry explants intended for in vitroculture. Academic Journals African Journal of Biotechnology, 12(39), 5749-5753.

Jayatillake, K. M. D. P. (2007). Studies on micrografting of Hevea brasiliensis and female florets culture of Hevea for somatic embryogenesis. Research Report of Bachelor of Science in Agriculture, University of Ruhuna, Kamburupitiya, Sri Lanka, 22-36.

Jimenez, V. M., Guevara, E., Herrera, J., \& Bangerth, F. (2001). Endogenous hormone levels in habituated nucellar Citrus callus during the initial stages of regeneration. Plant Cell Report, 20, 92-100. https://doi.org/10.1007/s002990000280

Madubuko, F. (2016). The influence of surface sterilization treatments on the initiation of 


\section{Macrothink}

Journal of Agricultural Studies

ISSN 2166-0379

2018, Vol. 6, No. 4

callus cultures in Vanilla planifolia. Thesis. Department of Science Faculty of Science and Technology University of Belize.

Montoro, P., Carron, M. P., Lardet, L., Demange, A. C., \& Leclercq, J. (2010). Biotechnologies of rubber tree (Hevea brasiliensis). Aus. Pac. J. MolBiol. Biotechnol., 18(1), 81-83.

Moradpour, M., Aziz, M. A., \& Abdullah, S. N. A. (2016). Establishment of in vitro culture of rubber (Hevea brasiliensis) from field-derived explants: Effective role of silver nanoparticles in reducing contamination and browning. Journal of Nanomedicine \& Nanotechnology, 7(3).

Nayanakantha, N. M. C., \& Seneviratne, P. (2007). Tissue culture of rubber: past, present and future prospects. Ceylon. J. Sci., 36(2), 116-125.

Seneviratne, P. (1996). Tissue culture for rubber. Bulletin of the rubber research Institute of Sri Lanka, 34, 26-31.

Seneviratne, P., Flegmann, A. W., \& Wijsekera, G. A. S. (1996). The positional effect of the explant on in vitro growth of axillary buds of Hevea brasiliensis. Journal of the Rubber Research Institute of Sri Lanka, 78, 69-78.

Sathyanarayana, B. N. D. B., \& Varghese. (2007). Plant tissue culture, practices and new experimental protocols. I.K. International Publishing House.

Zhao, H., Jia, R. Z., Zhu, Y. J., Guo, A. P., Zengand, H. C., \& Peng, M. (2015). Efficient induction, proliferation and regeneration of rubber tree. The Journal of Animal and Plant Sciences, 25, 134-140

\section{Copyright Disclaimer}

Copyright for this article is retained by the author(s), with first publication rights granted to the journal.

This is an open-access article distributed under the terms and conditions of the Creative Commons Attribution license (http://creativecommons.org/licenses/by/4.0/).s 